Emir. J. Food Agric. 2009. 21 (1): 40-47

http://cfa.uaeu.ac.ae/ejfa.shtml

\title{
Contribution to the systematic study of grasshopper fauna (Orthoptera, Caelifera) and some bio-ecological aspects of economic importance of species in the Constantine region (Eastern Algeria)
}

\author{
N. Benkenana and A. Harrat \\ Laboratory of Bio-systematics and Ecology of Arthropods, Department of Animal Biology. \\ Mentouri University of Constantine, Constantine, Algeria
}

\begin{abstract}
The inventory of the grasshopper and locust fauna in the Constantine region (Eastern Algeria) revealed the presence of 30 species, divided into four families, Acrididae, Pyrgomorphidae, Pamphagidae and Acrydiidae. Among these families, we found that Acrididae is the best represented one with eight subfamilies. Subfamily Oedipodinae is the largest, consisting of $\mathbf{1 0}$ species. The subfamilies of Catantopinae, Truxalinae and Pyrgomorphinae are represented by only one species each. The value of the Shannon Weaver index (3.7 bits) shows that the grasshopper population is more or less diverse, as the Equitability value ( 0.89 bits) shows how this species is in balance. The species Anacridium eagyptium, Acrotylus patruelis patruelis, Pezotettix giornii and Ocneridia volxemii appear to be of economic importance in the region of Constantine, Algeria.
\end{abstract}

Keywords: Acrididae, Anacridium eagyptium, Caelifères, Constantine, inventory.

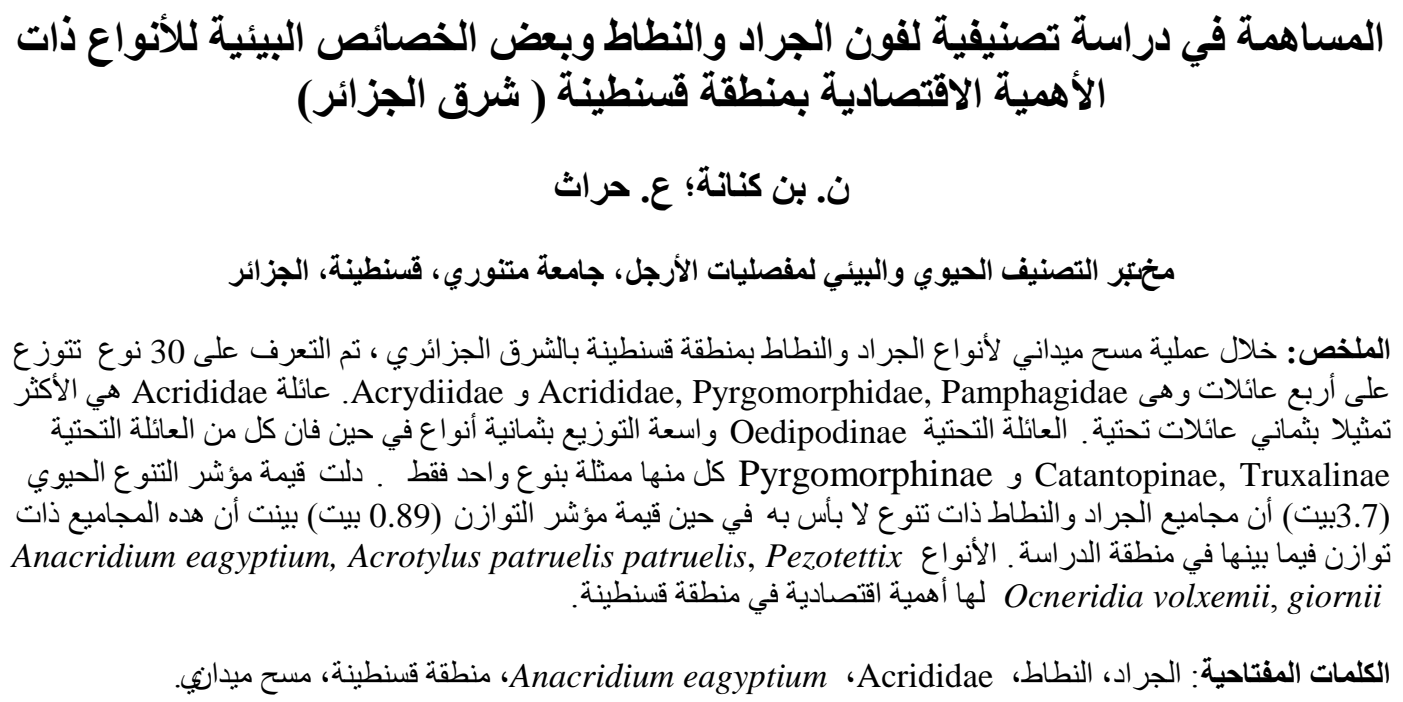

\section{Introduction}

Every year locusts and grasshoppers cause damage to crops and millions of people die from hunger. In addition to the loss of human lives, a number of areas have suffered from famine; entire regions have had to be abandoned (Appert and
Deuse, 1982). Locusts are probably the most formidable enemy of man since the onset of agriculture. Algeria occupies a significant part of the area inhabited by locusts.

Although only a few species are considered serious pests, other nongregarious species can become very 
dangerous when climatic conditions facilitate their multiplication. Therefore, it is necessary to have comprehensive knowledge of all locust species that settle in a territory.

\section{Presentation of the study area}

The study was conducted in the Constantine area, which covers 2287 square kilometres and is located in the heart of eastern Algeria (Fig. 1), of coordinates $36^{\circ} 36$ 'N latitude and $6^{\circ} 62^{\prime} \mathrm{E}$ longitude. It is $431 \mathrm{~km}$ from the capital Algiers in the west and bordered by the region of Skikda in the north at a distance of $89 \mathrm{~km}$. To the south, Constantine shares its border with the Oum El-Bouaghi region, to its east lies Guelma and to its west is the Mila region (Anonymous, 2004).

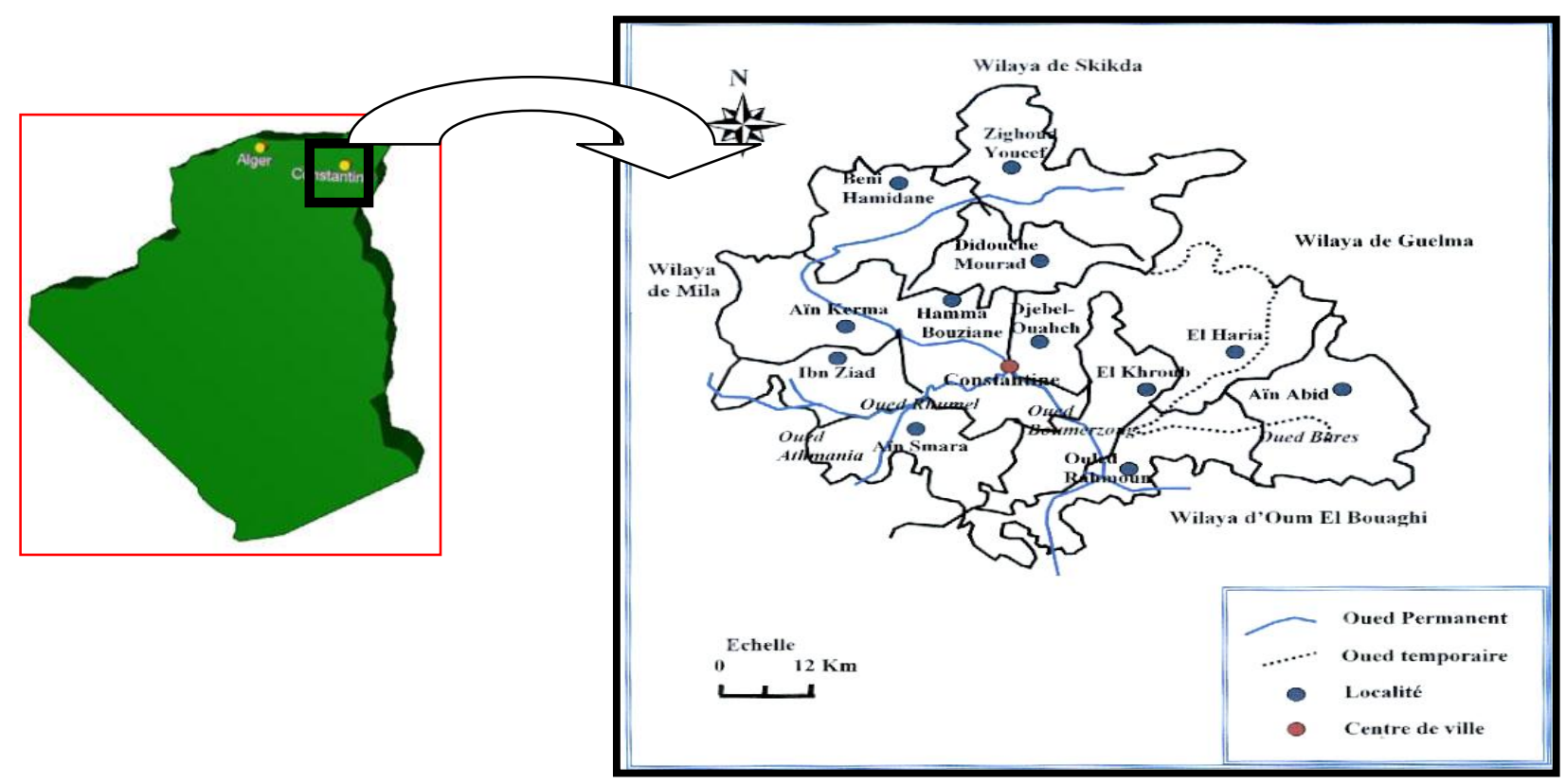

Figure 1. Administration limit of the Constantine region (LOUADI, 1999).

\section{Materials and Methods}

\section{Sampling}

The purpose of sampling is to obtain an instant image of the locust population structure (Lecoq, 1978; Voisin, 1986). There are various methods of capture used to collect the locusts in relation to their habitats. The methods by Lecoq (1978), Voisin (1980, and 1986) and Legall (1989) were used in this study. During our investigation, we used the quadrant method which is an accurate count of the number of individual locusts present in a welldefined area.
The quadrant method defines in each station an area of 100 square meters; within each square we sampled squares with nine square meters $(3 \mathrm{~m} \quad \mathrm{x} 3 \mathrm{~m})$. Techniques for sampling species are pickup applied to forms, fauchoir net used to catch adults and the capture by hand as the best ways to harvest the locust. The study spanned November 2004 to October 2005. During this period, sampling was repeated at a frequency of two times per month.

\section{Preparation and storage of the locust species}

Materials used for the conservation of 
orthopters were a pincer, a layer, entomologic pins for spreading and fixing the individuals and a collector box for keeping the insects. In order to ensure better preservation, naphthalene was added to the boxes; a binocular lens was used for observing the morphological criteria.

The samples of locusts meant for study were sacrificed in a jar containing potassium cyanide. They were then placed on the layer with entomologic pins planted in the thorax, with the elytra and right wing laid out to form a right angle with the body. Finally, the locusts were allowed to dry in collection boxes, each attached with a tag bearing the details of date, place of collection and the name of the species.

\section{Identifying the locust species}

The systematic identification of species of Orthopterans was done with the help of several key determination techniques described by Chopard (1943), Jago (1963), Launois (1978), Voisin (1980) and Ihsan (1988).

\section{Ecological analysis \\ The quality of sampling}

The quality of sampling is the ratio of species once contacted by the total number of observed (Blondel, 1979). The sampling quality is great when the $\mathrm{A} / \mathrm{N}$ is small and close to zero. In the equation: $\mathrm{Q}=\mathrm{a} / \mathrm{N}, \mathrm{a}=$ the number of species contacted once and $\mathrm{N}=$ total number of records.

\section{Total wealth}

The biological richness is the total number of species observed during $\mathrm{N}$ surveys (Ramade, 1984).

\section{Diversity index of Shannon-Weaver}

According to Frontier (1982) the most commonly used diversity index is that of Shannon-Weaver. To measure the diversity of the locusts we used the ShannonWeaver Index using the formula:

$$
\begin{aligned}
& H^{\prime}=-\sum_{i=1}^{i=s} \frac{n i}{N} \log _{2} \frac{n i}{N} \\
& \text { Or } \\
& \mathrm{H}=-\Sigma \mathrm{Pi} \ln \mathrm{Pi}
\end{aligned}
$$

where $\mathrm{S}=$ the number of species;

$\mathrm{Pi}=\mathrm{ni} / \mathrm{N}$ is the probability of meeting of the rank of species $i$; Neither the number of individuals of each species in the sample;

$\mathrm{N}$ : the number of individuals of all species; $\mathrm{H}$ : the diversity index of the sample.

The diversity index gives the specific richness and relative abundance of the species, thus reflecting the biological balance (Dajoz, 1971).

\section{Equitability index}

The Equitability index described as the ratio between diversity $\mathrm{H}$ bay and the diversity maximum $\mathrm{H}^{\prime}$ max was calculated using the formula: $\mathrm{E}=\mathrm{H} / \mathrm{H}$ 'max, where $\mathrm{E}$ $=$ Equitability index; $\mathrm{H}^{\prime}=$ diversity index of Shannon-Weaver calculated; $\mathrm{H}^{\prime} \max =$ diversity index up; $\mathrm{H}^{\prime}=\log 2 ; \mathrm{S}=$ the total wealth. The value of equitability calculated varied from 0 to 1 .

\section{Results}

\section{Inventory}

The inventory of the surveyed species demonstrated the presence of 30 locust and grasshopper species that belong to families Acrididae, Pyrgomorphidae, Pamphagidea and Acrydiidae. Among these the Acrididae family is best represented both in number of species and individuals.

Details of the inventory of the locust and grasshopper species are described in Table 1; Figure 2 shows the percentage of different subfamilies identified. 
N. Benkenana and A. Harrat

Table 1. Classification and inventory of locust and grasshopper species in the Constantine region.

\begin{tabular}{|c|c|c|}
\hline Family & Subfamily & Species \\
\hline \multirow[t]{3}{*}{ Pamphagidae } & Pamphaginae & Pamphagus elephas (Linné, 1758) \\
\hline & & Ocneridia volxemii (I. Bolivar, 1878) \\
\hline & & Pamphagus longicornis (Bolivar, 1878) \\
\hline Acrydiidae & Acrydiinae & Paratettix meridionalis (Rambur, 1839) \\
\hline Pyrgomorphidae & Pyrgomorphinae & Pyrgomorpha cognata minima (Uvarov 1943) \\
\hline \multirow[t]{25}{*}{ Acrididae } & Calliptaminae & Calliptamus barbarus barbarus (Costa 1836) \\
\hline & & Calliptamus wanttenwylianus (Pantel 1896) \\
\hline & Eyprepocnemidinae & Eyprepocnemis plorans (Charpentier, 1825) \\
\hline & & Heteracris adspersus (Redtenbacher 1889) \\
\hline & & Heteracris harterti (I. Bolivar, 1913) \\
\hline & Catantopinae & Pezotettix giornai (Rossi, 1794) \\
\hline & Cyrtacanthacridinae & Anacridium aegyptium (Linné, 1764) \\
\hline & & Schistocerca gregaria (Forskal, 1975) \\
\hline & Gomphocerinae & Dociostaurus jagoi jagoi (Soltani,1983) \\
\hline & & Euchorthippusalbolineatus albolineatus(Lucus, 1849) \\
\hline & & Ochrilidia geniculata(I.Bolivar, 1913) \\
\hline & & Ochrilidia gracilis gracilis (Kraus, 1902) \\
\hline & Acridinae & Aiolopus thalassinus thalassinus (Fabricius, 1758) \\
\hline & & Ailopus strepens (Latereille,1804) \\
\hline & Oedipodinae & Locusta migratoria (Linné,1758) \\
\hline & & Oedipoda fuscocincta fuscocincta (Lucas, 1849) \\
\hline & & Oedipoda miniata miniata (Pallas, 1771) \\
\hline & & Oedipoda caerulescens sulfurecens (Saussur,1884) \\
\hline & & Oedaleus decorus (Germar,1826) \\
\hline & & Sphingonotus caerulans(Linné, 1767) \\
\hline & & Sphingonotus rubescens (Walker,1870) \\
\hline & & Sphingonotus azurescens (Rambur, 1838) \\
\hline & & Thalpomena algeriana algeriana (Lucas, 1849) \\
\hline & & Acrotylus patruelis patruelis (Herrich-schaeffer, 1884) \\
\hline & Truxalinae & Truxalis nasuta (Linné, 1758) \\
\hline
\end{tabular}


Emir. J. Food Agric. 2009. 21 (1): 40-47

http://cfa.uaeu.ac.ae/ejfa.shtml

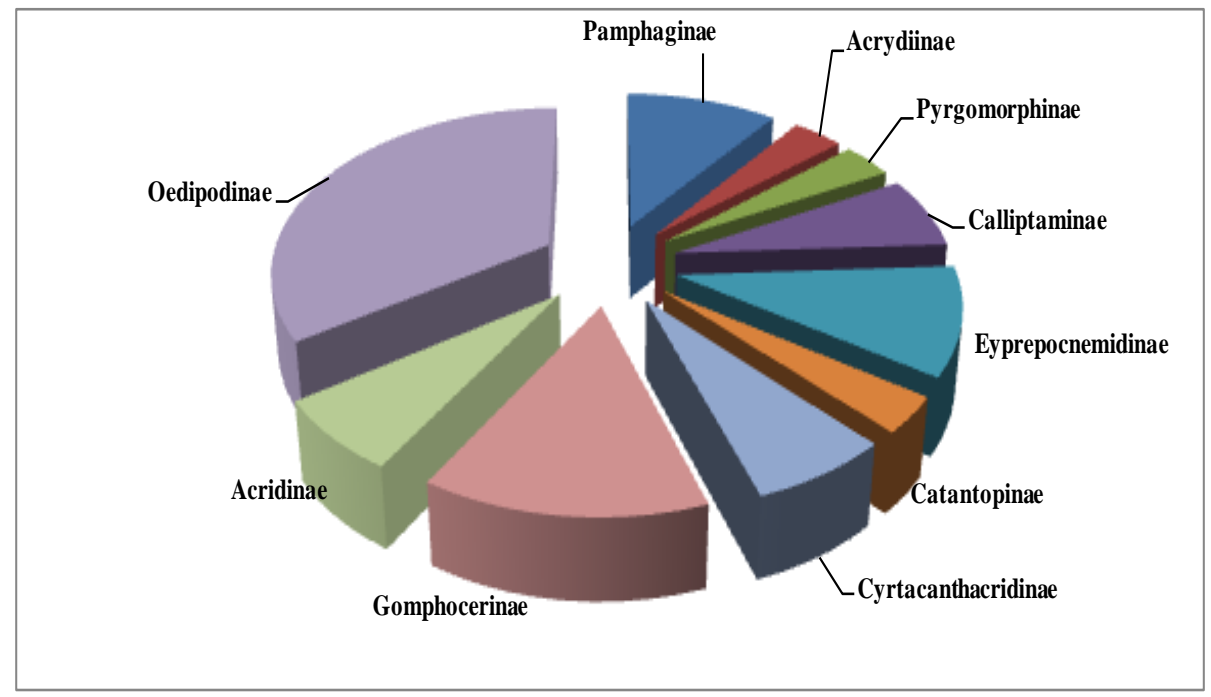

Figure 2. Percentage of different sub-families identified in the Constantine region.

\section{Ecological indices}

As the value of $\mathrm{A} / \mathrm{N}$ is close to zero, the sample quality is good. The value of the Shannon-Weaver index (3.7 bits) shows that the locust population is more or less diverse as the Equitability Index value (0.89 bits) shows that the grasshopper's species are in balance (Table 2).

Table 2. Results for the ecological indices.

\begin{tabular}{lc}
\hline Ecological indices & Value \\
\hline Quality sampling & 0.005 \\
Total wealth & 30 \\
Diversity index of Shannon-Weaver & $3.78 \mathrm{bits}$ \\
Equitability Index & $0.89 \mathrm{bits}$ \\
\hline
\end{tabular}

\section{Discussion}

The census of wildlife grasshoppers in the study area totals 30 species. The Acrididae family is the most important one and is represented by 25 species of locusts. Lauveau and Benhalima (1987) cited 140 species of Caelifères in Algeria. 12 families found in the process of this study represent $66.66 \%$ of all Orthoptera. The subfamily Oedipodinae alone has 10 species, or $33.33 \%$. Subfamily Gomphocerinae was represented by 4 species, or $13.33 \%$, while the Pamphagidae and Eyprepocnemidinae families each had $10 \%$ (3 species) of representation. The subfamilies

Dericorythinae,

Pyrgomorphinae, Cyrtacantacridinae, Catantopinae, Truxalinae, Acrydiinae each had one species, or $3.33 \%$ of all Caelifères.

The distribution of locust species depends not only on the differences among them but also bio-geographical climate change. According to Chopard (1943) Orthoptera prefer warmer and dry weather.

Among the species that were surveyed in the region of Constantine we have Paratettix meridionalis, which is very common in the damp areas and along streams (Chopard, 1951). The presence of this species had been earlier reported in the region of Constantine (Moussi, 2002). The 
Mitidja Paratettix meridionalis species transition from larvae to adults during all months of the year and was found in the same region (Hamadi, 1998). The

Pezotettix giorni species has a very long life. The larvae and adults of this species have been captured in the Constantine region throughout the year. Our results agree with those of Felloune 1989, Guerciour1990, Bentamer 1993 and Hamdi 1998, and similarly to Seghier 2002.

Acrotylus patruelis patruelis is common in the Constantine region and according to Chopard (1943), this species is found in the adult form most of the year. These findings were confirmed by Hamdi (1989, 1992) on the Algerian coast, by Guerciour (1990) in the region of Lakhdaria and by Bourahla (1990) in the region of Chrea. These works show that the locust is in the imaginal over a period of many years and has only one generation per year. Mitidja (Benrima, 1993) and the Sahara septentrional (Ould -Elhadj, 1991) stated that Patruelis has one generation per year. In the region of Ghardaia, Zergoun (1991), Douadi (1992) and Babaz (1992) indicate that this locust species has one or two generations per year.

Anacridium eagyptium is a species large in size, found in the Biskra and Constantine region (Moussi, 2002). Benharzallah (2003) reported that it was found in the region of Batna. This species prefers cultivated areas, especially in hate and shrubs.

Ocneridia volxemii (I. Bolivar, 1878) species is very common in the highlands of Morocco. According to Chopard (1943) this species had a large outbreak and caused great damage. The same phenomenon was reported by Benharzallah (2004) in the Batna region.

Sampling was done with quality precision, the value of $\mathrm{A} / \mathrm{N}$ was calculated as being close to zero, and was found to be 0.05 . The species was identified only once and in one case was found to be Truxalus nasuta, when it was found as an adult. It seems that this species prefers more arid habitats to pulluler, and was seen in the region of Biskra (Moussi, 2002), and the region of Batna (Benharzallah, 2003).

The total wealth varies between regions and the sampling times. The value of the total wealth of locusts in the region of Constantine is 30 species. Moussi (2002) reported the presence of 21 locust species in the region of Biskra, Benharzallah (2003) found the total wealth to be 22 species in the Batna Region.

The diversity index was calculated to be 3.78 bits, and was explained by increased plant diversity in the region, and the wet climate with a high average temperature, all of which provide conditions conducive to the development of locust species. According to Viera Silva (1979) and Blondel (1979), a community is more diversified when the index $\mathrm{H}$ was larger. According to Dajoz (1971), the diversity is dependent on the stability of the environment and the climate. The value of Equitability is close to 1 (0.89), therefore corresponding to the population balance between them. The latter seem to be characteristic of our study plots.

This indicates that the environment is stable and the locust population structure is an almost uniform and balanced one. According to Frontier (1982), a community with a small number of relatively abundant species other rare apparainrent a less diverse community including at the same total number of species frequencies more evenly distributed. Similarly, Lachelah (2002) reported that the value of Equitability is the highest at 0.98 , at the areas of cultivation. This is because the species live in a balance, so their environment is stable.

\section{Conclusion}

There are a total of 30 species of grasshoppers and locusts in the Constantine region that belong to the suborder of Caelifères. They are divided into the four families, Pamphagidae, 
Pyrgomorphidae, Acrydiidae and Acrididae. The species Anacridium eagyptium, Acrotylus patruelis patruelis, Pezotettix giornii and Ocneridia volxemii appear to be of economic importance in the region of Constantine.

Through this work, we have contributed to the identification of locust species in eastern Algeria. We intend to conduct very detailed studies on the locust species that can access the status of crop pests, namely systematics, bio-ecological, diet, morphometry and to recommend methods of struggle.

\section{References}

Anonymous. 2004. Algerian Wetlands Atlas (IV) of International Importance. Ministry of Agriculture and Rural Development, General Directorate of Forests. pp. 53-57.

Appert. J. and J. Deues. 1982. Pests of crops and vegetables in the tropics [in French] ED. Maisonneuve and La Rose. T2.Paris. pp. 420.

Babaz, Y. 1992. Bioecological study of orthopteres in the region of Ghardaia. [in French] Engineer thesis. Agro. inst. Univ Blida. Algeria. pp 91.

Benharzallah. N. 2003. Contribution to the inventory and bio-systematic study of wildlife acridien in the region of the Aures (Batna). Algeria. [in French] Master thesis. Univ Constantine. Algeria. pp.180.

Benrima. A. 1993. Bioecology and study of diet of species encountered in two Orthoptera station located in Mitidja.Anatomical and histological study of the digestive tract of Dociostaurus jagoi jagoi. [in French] Master thesis. Agro. inst. Nat. Agri. El-Harrach. Algeria. pp.190.

Bentamer. N. 1993. Bioecology study of Orthoptera and development of ovarian
Calliptamus barbarous (Costa, 1836) in the region of Ain El-Hmmam (Tizi Ouzou). [in French] Engineer thesis. Agro. Inst. Nat. Agro. El-Harrach. Algeria pp. 71.

Bourahla . E. 1990. Comparison of the fauna orthotérologic between some stations of soumaâ and of cheréa. [in French] Engineer thesis. Agro. inst. Nat. Agr. El-Harrach. Algeria. pp 144.

Blondel. J. 1979. Biogeography and ecology. [in French]. Ed Masson. Paris. pp. 173.

Chopard, L. 1951. Fauna of France 56. Orthortoides. [in French]. pp. 359.

Chopard. L. 1943. Orthoptèroides North Africa. [in French]. Ed Rose Bookstore. Coll: Fauna of the French Empire. Paris. pp. 405.

Dajoz. R. 1971. Specific ecology. [in French] Ed. Gauttier Villas. Paris. pp. 505.

Douadi. B. 1992. Contribution to the study of bio-ecological orthoptérologiques settlement in the region of Guerrara (Ghardaia). Ovarian development of Acrotylus patruelis (Herrich-Schaeffer, 1838). [in French] Ingénieur thesis. Agro. Ist. Nat. Agro. El-Harrach. pp. 75.

Fellaouine. R. 1989. Bioecology of Orthoptera in the region of Sétif. [in French]. Master thesis. Ist. Nat.agro. El-Harrach. Algeria. pp. 127.

Frontier. S. 1982. Sampling strategies in ecology. [in French]. Ed Masson. Paris. Collo. Ecology. N17. pp. 494.

Guecioueur. 1990. Bioecology of wildlife orthoptérologie in three stations in Lakhdaria region. [in French] Engineer thesis. Agro. inst. Nat. Agr. ElHarrach. Algeria. pp 71. 
Hamadi. K. 1998. Bioécology study stands in orthoptérologic in Mitidja. Study of the biological activity of extracts acridifuge plants towards Ailopus strepens (Laterille, 1804). [in French]. Engineer thesis Agro. inst. Nat. Agr. El-Harrach. Algeria. pp. 14-49.

Hamdi. H. 1989. Contribution to the ecological study of Orthoptérologic in mid region of northern Algeria and the region of Gabes (Tunisia). [in French]. Engineer thesis. Agro. inst. Nat. Agr. El-Harrach. Algeria. pp. 127.

Ihsan, S. 1988. Systématique locust the Middle East. Physiological aspect and an ultra structural embryogenesis with diapause in Locusta migratotia (Linnaeus, 1758). [in French]. Ph.D dissertation. Univ. P. M. Curie, France. pp. 208.

Jago, N. 1963. A revision of the genus Calliptamus (Orthoptera, Acrididae). [in French]. Bull. Brit. Mus. Nat. Hist. Entomology. No.9. pp. 289-350.

Launois, M. 1978. Manual practice of identification of the main members of the Acrididae of the sahel. [in French] Ministry of the cooperation and G E R D A T (Paris). pp. 303.

Lechelah. N. 2002. Contribution to the bioecological study of the Orthoptera and diet of Ochrilidia tibialis and Pyrgomorpha cognata in Guémar region (El_Oued). [in French] Master thesis, Ist. Nat.agro. El-Harrach. Algeria. pp190.

Lecoq, M. 1978. Biology and population dynamics of a locust in the Sudanese zone of Africa (Orthoptera, Acrididae). [in French]. Ann. Soc. Ento. France 14(4). pp. 603-681.

Legall, P. 1989. The choice of food plants and specialization among trophic
Acridoidea (Orthoptera). [in French] Bull. School, T. 20:245-261.

Louveaux. A. and T. Benhalima. 1987. Catalog Acidoidea Orthoptera of North-West Africa. [in French]. Bull. Ento. France. 91 (3-4). pp 73-87.

Ould Elhadj, M. D. 1991. Bio-ecology of locusts and grasshoppers in three areas of study in Sahara. [in French] Master thesis. Agro. inst. Nat. Agr. ElHarrach. Algeria. pp. 85.

Ramade. F. 1984. Elements ecology. Ecol. Frond. Ed. Mac. Graw-Hill. Paris. pp. 379.

Seghier. M. 2002. Bio-ecological study of Ortoptères in three different muilieux. Diet Calliptamus barbarus (Orthoptera, Acrididae) in three regions of Media. Master thesis. Agro. inst. Nat. Agri. El-Harrach. Algeria pp.181.

Viera Silva. J. 1979. Introduction to ecological theory. [in French] Ed Masson. Paris. pp.112.

Voisin, J. F. 1980. Thinking about a simple method of sampling stands of Orthoptera in an open environment. [in French] Acrida. T. 9 No. 3-4:159-170.

Voisin, J. F. 1986. A simple method to characterize the abundance of Orthoptera in open environments. [in French] The entomologist. Paris. pp. 42:113-119.

Zergoun. Y. 1991. Contribution to the study of bio-ecological stands orthoptérologic in the region of Ghardaia. [in French] Engineer thesis. Agro. inst. Nat. Agr. El-Harrach. Algeria. pp. 73.

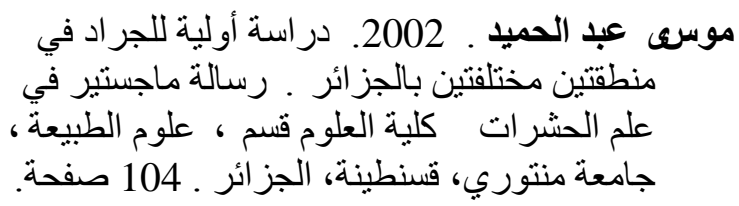

